\title{
220 YEARS FROM THE BIRTH OF THE MEDICAL AND NATURAL SCIENTIST KARL ERNST VON BAER
}

\author{
RAIK-HIIO MIKELSAAR \\ Professor Emeritus of the University of Tartu, \\ Chairman of the Karl Ernst von Baer Foundation, Estonia
}

Karl Ernst von Baer, our most eminent natural and medical scientist of all times, was born in Piibe manor, Järva county, Estonian guberniya, on 28 February 1792 (New Style). His sphere of activities was exceptionally broad, ranging from medicine, zoology, embryology, entomology, ornithology and ichthyology to bibliography, botany, climatology, geomorphology, archaeology, ethnology and anthropology.

Having spent his childhood at the manors of Lasila and Piibe and studied for three years (1807-1809) at Tallinn Cathedral School, Karl Ernst acquired higher education at the Faculty of Medicine at the University of Tartu (Kaiserliche Universität Dorpat). The theme of his doctoral dissertation was De morbis inter esthonos endemicis (On Estonians' Endemic Diseases). After graduating from the university, he continued his education at the medical institutions of Berlin, Vienna and Würzburg from 1814-1817, but being disappointed at that time's medical science, he became interested in comparative anatomy. As he had contacts with Ignatius Döllinger and Karl Friedrich Burdach, he managed to get employment in this field of research at the University of Königsberg for a longer time (1817-1834), first as a prosector, later as a professor.

At the University of Königsberg, Karl Ernst von Baer taught mainly anatomy of invertebrates and vertebrates, but in the winter term of $1817 / 1818$ he also lectured on anthropology. In 1819 he received a proposal to establish a zoological museum there. Working at that museum, he discovered the mammalian (more precisely, the dog's) ovum in 1827 and wrote the research paper De ovi mammalium et hominis genesi (On the genesis of the ovum of 
mammals and humans). In 1828 Karl Ernst von Baer published his pioneering monograph about the regularities of embryonic development of animals Über Entwicklungsgeschichte der Thiere (On the Development History of Animals). This paper shows that Baer was the discoverer of embryonic rudiments of the spinal cord, the brain vesicles, the eye and the internal organs. Studying the development of the fertilized ovum of the frog, he was the first to describe its segmentation (Theilung). Baer named the particles formed by segmentation ElementarTeilchen - histologische Elemente (elementary particles - histological elements), and he also described the halving of the nucleus. As the aforementioned particles correspond to cells in their present-day sense, Karl Ernst von Baer, along with Matthias Jakob Schleiden and Theodor Schwann, can be considered one of the founders of the cell theory. Moreover, his embryologic discoveries also served as a basis for developing of Darwin's evolutionary tree and theory.

From 1834-1867 Karl Ernst von Baer lived in St. Petersburg where he worked at the Academy of Sciences as Academician for Zoology and head of the foreign literature department of the Academy's library, thereafter at the Russian Ministry of Public Education where he drafted the new University Act. Within this period he also worked at St. Petersburg Academy of Military Medicine as Professor of Comparative Anatomy and Physiology (1841-1852). Karl Ernst von Baer participated in numerous expeditions to Novaya Zemlya, Lapland, the shores of the White Sea and the Arctic Ocean, the Volga River, the Caspian and Azov Seas and Lake Peipsi. From 1842-1843 he published a groundbreaking research paper on the geological and physical geographical properties of permafrost. In 1845 Baer initiated the foundation of the Russian Geographical Society. Based on ichthyological studies on Estonian water bodies (1851-1852), he developed the ecological approach to ichthyology. In 1856 he discovered the law of the asymmetry of river banks which became widely known. In 1860 he was President of the Russian Entomological Society and in 1861 chairman of an anthropological conference in Göttingen.

During the last years of his life (1867-1876), Karl Ernst von Baer lived in Tartu where, from 1869, he was President of Tartu Naturalists' Society. Baer died on 28 November 1876 (New Style) and was buried in Raadi cemetery in Tartu.

In 1886 a monument in memory of Karl Ernst von Baer was erected on Toome Hill in Tartu. It was made by sculptor Alexander Opekushin from Yaroslavl at the initiative of St. Petersburg Academy of Sciences. In the Republic of Estonia, too, the heritage of the scientist has been increasingly appreciated. In 1960, at the initiative of the Estonian Academy of Sciences, a 
memorial stone was laid at the location of his birth house at Piibe. In Karl Ernst von Baer's last residence at 4 Veski Street in Tartu, the so-called Baer House, an exhibition covering his life and work was opened on 29 September 1976, and the Baer Award and Medal were established to honour the best Estonian medical and natural scientists. Now the building accommodates the Centre for Science Studies (director Erki Tammiksaar) of the Estonian University of Life Sciences, which has turned the exhibition into a permanent display that is constantly being developed. On 28 February each year, on the scientist's birthday, the Centre organises the Baer Day which begins at his monument on Toome Hill with a memorial speech and laying of flowers. In spring 2010 the Centre helped to renovate the Baer tower at the school located in the main building of Lasila manor.

On 16 November 2002, twenty people with a sense of mission (mostly scientists) bought the only preserved building of Piibe manor, the former house of the manager of the estate, in order to arrange events in Karl Ernst von Baer's memory and other educational events there. In 2008, 2.5 hectares of the former manor lands were bought, which, together with the building acquired earlier, form the Baer landed property. On 6 June 2009, 28 people established the Karl Ernst von Baer Foundation (abbreviated as KEBF, in Estonian Karl Ernst von Baeri Fond, in German Karl Ernst von Baer Stiftung). The aims of the Foundation are: (1) to value and develop the heritage of the eminent natural scientist Karl Ernst von Baer by supporting corresponding research and familiarising the public with scientific treatment of the world and its applications; (2) to promote educational and cultural life on the territory of the former Piibe manor and nature tourism. The Board of the Foundation includes Raik-Hiio Mikelsaar (chairman), Ingrid Mesila and Monika Prede; its Council members are Mati Kaal (chairman), Jüri Martin, Toomas Frey, Andres Kollist, Timo Vunder and Jaan Kaplinski. The other people who established the KEBF were Mart Viikmaa, Rein Vihalemm, Lembi Kogerman, Anto Raukas, Lauri Jõesaar, Jaan Jõers, Ene Talpsep, Ülo Tölp, Arvo Haug, Katri Ling, Karl Heinz Gast (Germany), Gudrun Veldre, Ragnar Viir, Sulev Järve, Laine Trapido, Peeter Normak, Heldur Sander, Lembit Dalberg, Tambet Teesalu and Triinu Vill.

From 2011-2012, with the approval of KEBF, $2.7 \mathrm{~km}$ long Piibe Baer Timeway (more precisely Cosmo-Geo-Bioway) was built at Raik-Hiio Mikelsaar's initiative and using his own resources. The route consists of a pedestrian and bicycle path and a deepened water canal. The Timeway gives a symbolic overview of the development of the universe from the Big Bang to the formation of the Solar System, and onwards, from the emergence of Life and its 
differentiation through different eras until the present. The Timeway was designed by REIB OÜ (Mairolt Kakko) and earthwork was done by Koidusära Metsatööd OÜ (Marko Pohlak).

From 8-10 June 2012, KEBF, Pandivere Development and Incubation Centre (PAIK) and the Ethics Centre of the University of Tartu organised a three-day event dedicated to Karl Ernst von Baer's $220^{\text {th }}$ birth anniversary. The first day ( 8 June 2012) began with opening remarks by Raik-Hiio Mikelsaar and Aivar Niinemägi (chairmen of KEBF and PAIK) at Baer's monument on Toome Hill. Art historian Enriko Talvistu analysed the uniqueness of the monument, and physicist Viktor Korrovits described the location of a windmill that had existed near Baer's last place of residence. Thereafter, a musical performance about Karl Ernst von Baer's life and work (script by Raik-Hiio Mikelsaar in cooperation with Mare Rand and Mart Viikmaa) was presented by the actors and musicians of the Vanemuine Theatre and the Emajõe Summer Theatre with help of the historian Eva Piirimäe. The performance began at the monument and continued in the building of the University of Tartu History Museum. On the second day (9 June 2012) the participants were taken on bus tours to the area of Baer's childhood home (Piibe, Kiltsi, Lasila, Porkuni, Võivere and Simuna), and a bonfire party was arranged near artist Hando Kuntro's Sunrise Hut on Emumägi Hill. On the third day (10 June 2012) a conference took place at Rakke community centre. The theme of its first session (moderators Raik-Hiio Mikelsaar and Aivar Niinemägi) was Karl Ernst von Baer, history and popularisation of science; the presenters were Cecilia Ödman (Sweden), Madis Linnamägi, Rein Einasto, Jaan Kasmel and Ken Kalling. The second session (moderator Kadri Simm) was Ethics and science; the presenters were Vilhjalmur Arnason (Iceland), Theda Rehbock (Germany), Kristi Lõuk, Andres Metspalu and Francesco Frassoni (Italy). The third session was a panel session (moderator Margit Sutrop) Ethics, society and science.

KEBF, PAIK, the Centre for Science Studies at the Estonian University of Life Sciences, and the University of Tartu History Museum are going to venerate the life of our great scientist Karl Ernst von Baer in the future as well. 


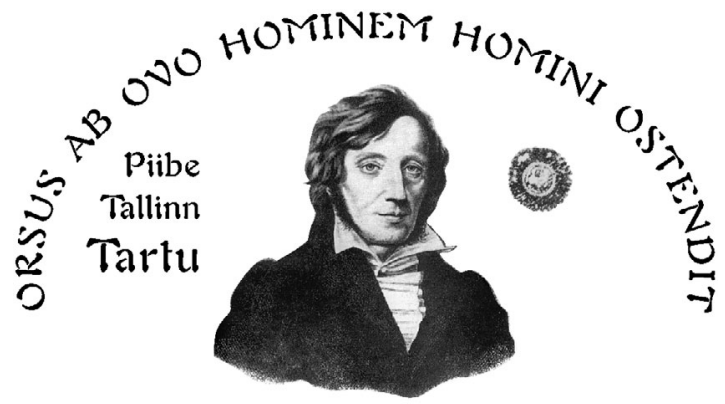

KARL ERNST VON BAER

$1792-1876$

Figure 1. Karl Ernst von Baer Memorial Medal

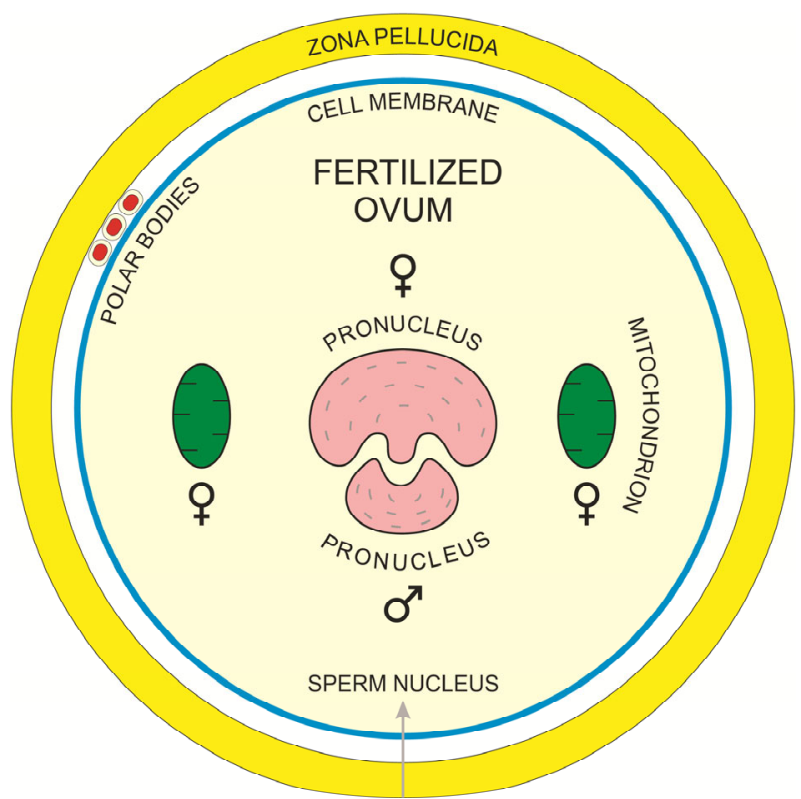

Figure 2. Mammalian fertilized ovum, discovered by Karl Ernst von Baer in Königsberg zoological garden (1827) and demonstrated nowadays as a macroflex-imitation at the end of Piibe Baer Timeway 


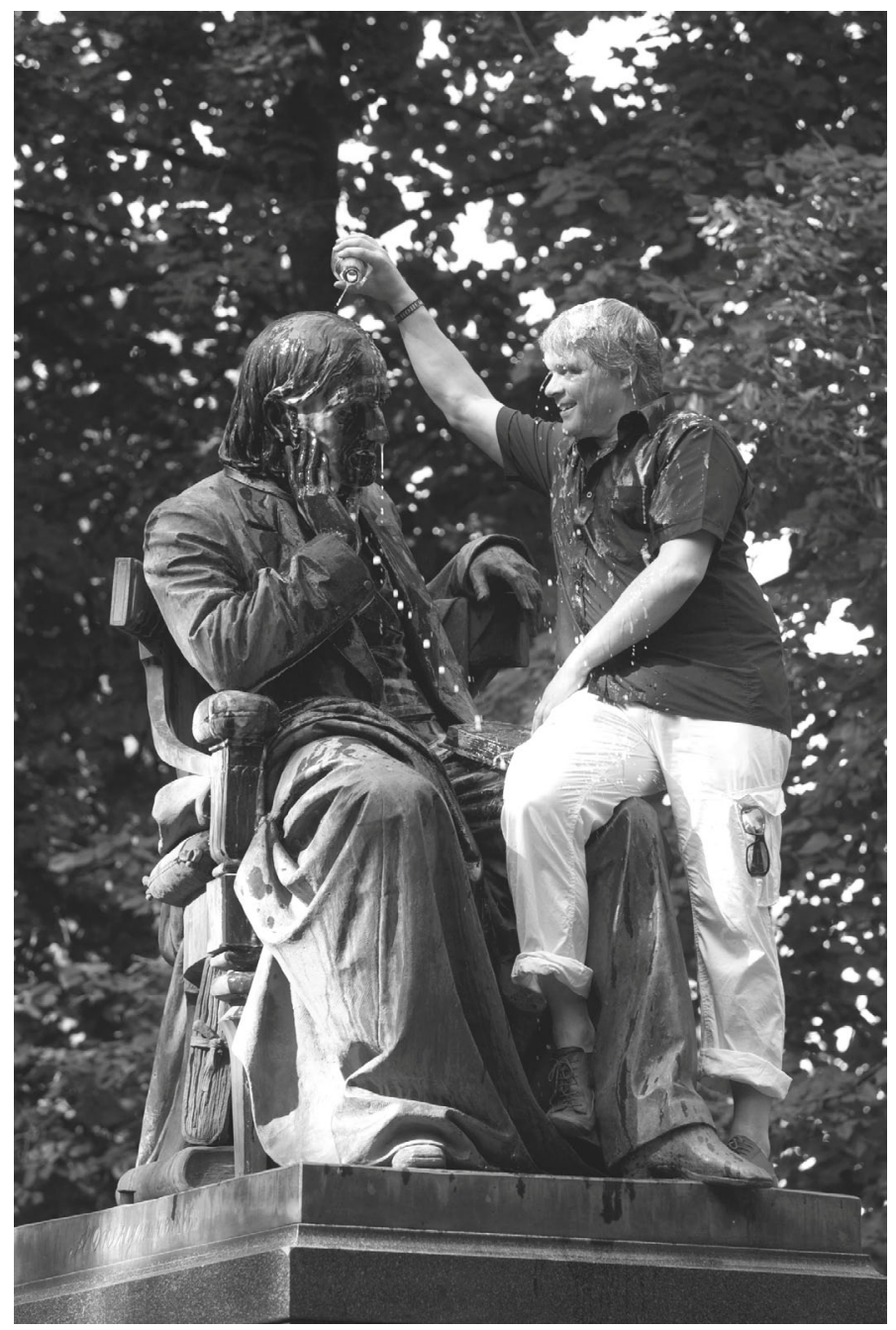

Figure 3. Baer's descendant Andreas Leo Findeisen washing the head of Baer's monument. The tradition of washing Baer's head was probably initiated by medical students in the 1950s. Photo by Aldo Luud. 


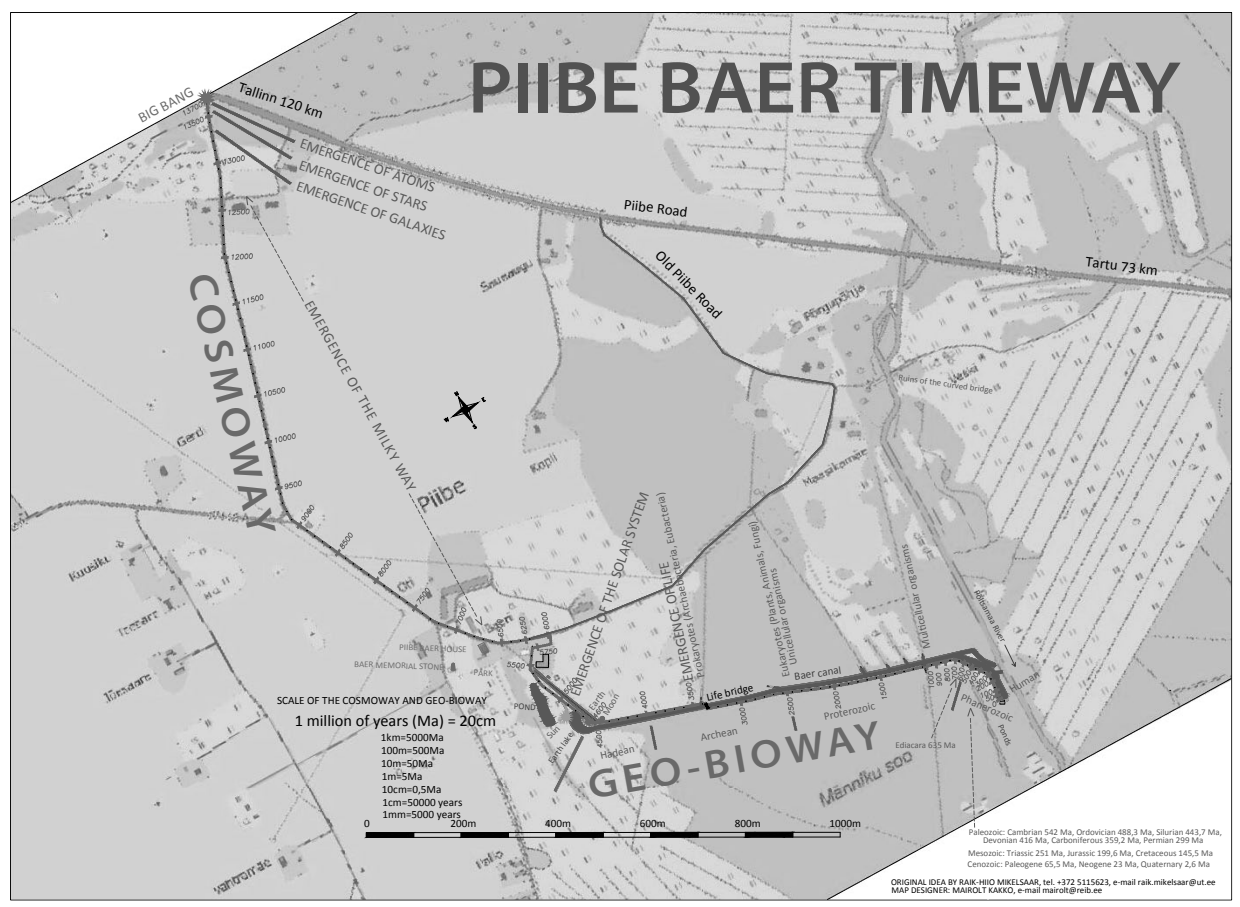

Figure 4. Map of Piibe Baer Timeway (Cosmo-Geo-Bioway)

\section{Address for correspondence:}

Raik-Hiio Mikelsaar

11-4 Jakobi, Tartu, 51005

E-mail: raik.mikelsaar@ut.ee 